Historic, Archive Document

Do not assume content reflects current scientific knowledge, policies, or practices. 

Rexerve

A99.9

F 76.324 WHE
Rodent Population Densities and Food Habits in Arizona Ponderosa Pine Forests

John G. Goodwin, Jr. and C. Roger Hungerford

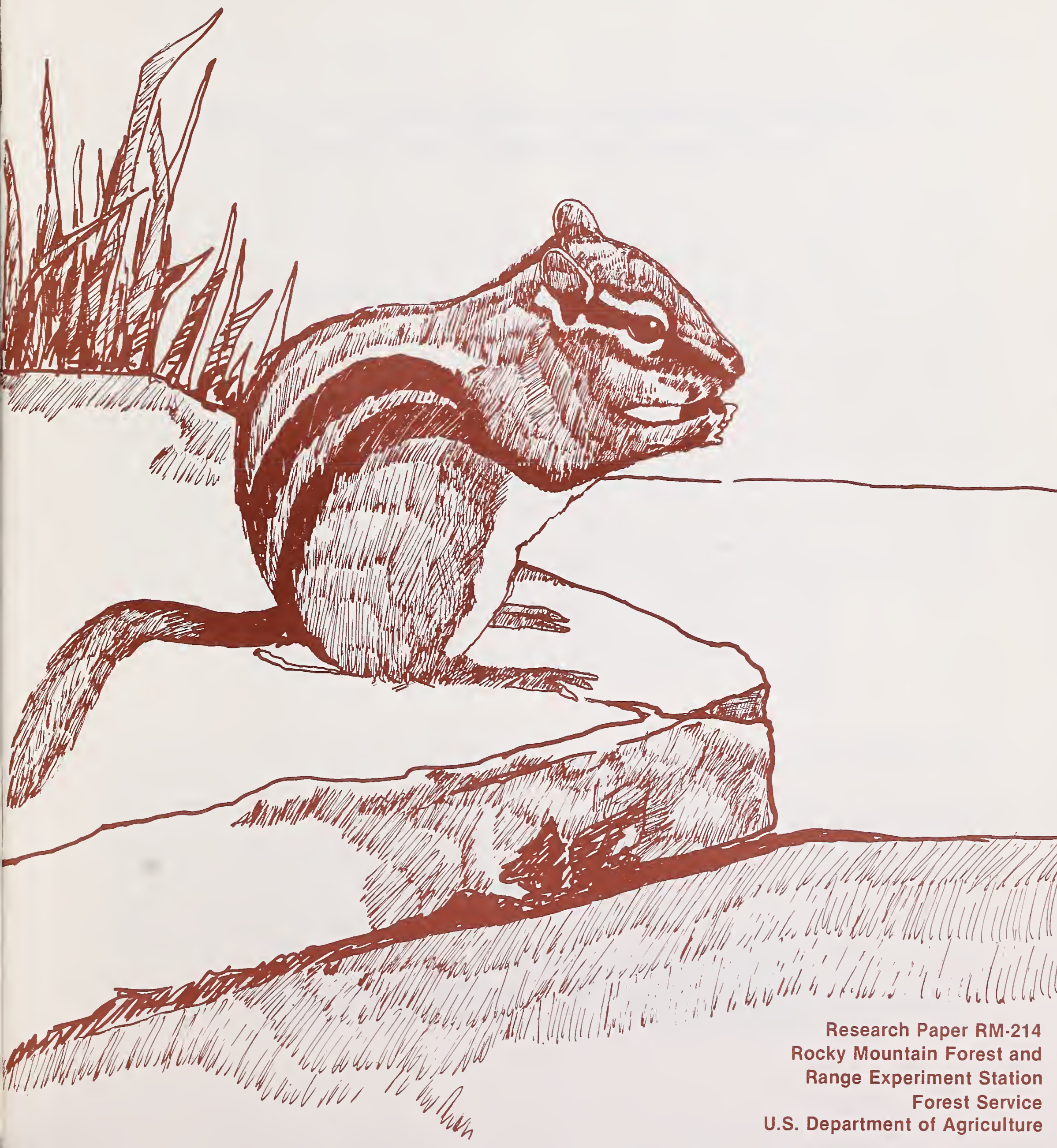




\title{
Rodent Population Densities and Food Habits in Arizona Ponderosa Pine Forests ${ }^{1}$
}

\author{
John G. Goodwin, Jr., Research Associate \\ and \\ C. Roger Hungerford, Professor of Biological Sciences \\ University of Arizona
}

\begin{abstract}
Habitat preference, effect of timber harvesting on population densities, and food habits were determined for small rodents inhabiting ponderosa pine in north-central Arizona. Peromyscus maniculatus was the major species, with a density of 1 to 11 per acre. Forbs were the primary summer food item for all rodent species. Seeds and flowers comprised $75 \%$ of the vegetative diet and leaves or stems $25 \%$. Approximately $85 \%$ of the total diet was vegetation, and $15 \%$ was insects.
\end{abstract}




\title{
245 \\ Rodent Population Densities and Food Habits in Arizona Ponderosa Pine Forests . \\ $=$
}

\author{
John G. Goodwin, Jr. and C. Roger Hungerford
}

\section{Management Implications}

Rodent population density and biomass are generally low in untreated ponderosa pine ${ }^{2}$ forests. Thinning of pine with its resulting slash increases density and biomass $200-1,000 \%$. The deer mouse is the most typical of the pine type. Its population density is directly related to the amount of slash and large logs on the ground. Logging operations normally increase the number of downed logs, improving the habitat for deer mice.

Brush mice and woodrats are normally found in high densities along rocky slopes but seldom inhabit pure pine stands. Windrowing slash can create "fingers" of habitat for these species and allow them to invade the pine stands. Mexican woodrats appear to be better adapted to different habitats than white-throated woodrats.

The cliff chipmunk is found along rock cliffs and in thinned pine stands. Density increases as the forest is thinned, but this species does not inhabit clearcuts. Altitudinal zonation limits cliff chipmunks to below 7,300 feet elevation. Graycollared chipmunks prefer mature forests above 7,300 feet. Along that boundary, interspecific competition favors the cliff chipmunk in open stands and the gray-collared chipmunk in more dense forests. The golden-mantled ground squirrel prefers areas above 7,300 feet elevation but inhabits both open and dense pine stands.

Pocket gophers inhabit both treated and untreated forests but prefer areas with deep topsoils. However, this species was not found in high densities on any of the study areas.

Thinning ponderosa pine forests would favor cliff chipmunks over gray-collared chipmunks where both species are present. Clearcutting would eliminate both species and the goldenmantled ground squirrel. However, the degree of thinning, when all slash is removed, would have little effect on other species. If cull logs and large diameter limbs are left scattered after thinning, deer mouse densities will increase in proportion to the increase in cover. When slash is piled or windrowed, brush mice and Mexican woodrats will move into the pine type, and deer mouse population density will increase slightly. Therefore, the treatment of slash, rather than the actual pine thinning, is the primary factor determining rodent density and species diversity.

Forbs were the primary food item for all rodent species during the summer. Seeds and flowers were preferred to other parts of the plant. Ponderosa pine seeds and seedlings did not contribute significantly to the summer rodent diet on the Beaver Creek Watershed.

\section{Introduction}

Rodents are an important part of the ponderosa pine ecosystem since they feed extensively on various plant species, and in turn, are fed upon by many terrestrial and avian predators. High rodent population densities can significantly affect plant survival or reproduction (Schmidt and Shearer 1971, Dingle 1956). A sudden drop in their population can stress predatory species forcing them to seek alternate food sources. Therefore, any treatments affecting rodent populations may also influence other plants or animals.

\footnotetext{
${ }^{2}$ Scientific names of plants and animals referred to in this paper are listed in the appendix.
}

Study Areas

The Beaver Creek Watershed is located on the Coconino National Forest approximately 30 miles south of Flagstaff, Ariz.

Vegetation types found on the Beaver Creek Watershed include ponderosa pine, alligator juniper, Utah juniper, and semidesert. However, this study was limited to the pine type generally found above 6,500 feet elevation.

The forest is primarily composed of ponderosa pine but contains some Gambel oak and alligator juniper (Brown et al. 1974). The basal area per acre of a typical stand includes 92 square feet of pine, 18 square feet of Gambel oak, and 5 square feet of alligator juniper (Brown et al. 1974). The 
size mixed classes are dominated by 2- to 10 -inch or 26-inch-plus trees, with a shortage of trees in the 14- to 24-inch class (Brown et al. 1974).

The soils are primarily clay or silty clay less than 2 feet deep and derived from basalt parent material (H. E. Brown 1971). Average precipitation varies within the watershed from about 22 to 28 inches per year (Price 1967). Topography within the pine type is dominated by a southwest aspect with a $5^{\circ}$ to $15^{\circ}$ slope dropping from about 7,600 to 6,500 feet. Several steep mountains rising to nearly 8,000 feet and several rocky canyons provide some variations in slope and aspect.

Understory vegetation beneath the undisturbed ponderosa pine is generally open, with about 124 pounds per acre of grasses and 58 pounds per acre of forbs and half-shrubs. Dominant grasses include bottlebrush squirreltail, mutton bluegrass, blue grama, and black dropseed. Important forbs include western ragweed, spreading fleabane, trailing fleabane, and showy aster (Brown et al. 1974).

This study was conducted on 6 of the 18 experimental watersheds: watersheds $8,10,11,13,14$, and 17 . Watershed 13 was untreated and served as the control area for comparison with the treated watersheds. Watersheds 11,14 , and 17 were treated between 1958 and 1971, and watersheds 8 and 10 were cut in 1974 while this study was in progress. Watershed descriptions and treatments are presented in table 1.

Rodent population densities were determined by intensive live trapping on a 4.17-acre site on each watershed studied. Each site was chosen to typify the habitat found on that watershed.

The site on watershed 13 contained a wide mixture of pine age classes ranging from overmature trees more than 24 inches in diameter to thickets of reproduction less than 2 inches in diameter. The ground was covered by pine needles, small twigs, and fallen trees. Grass and forb growth was very sparse. The southern edge of the site bordered on one of the two rocky canyons found on the watershed.

The site on watershed 14 was dominated by thinned pine and oak but included portions of two strip cuts. Some slash had been piled and burned, but much of the cut reproduction (less than 2 inches in diameter) remained on the ground along with many downed logs 8 inches or more in diameter. The ground litter had also been disturbed by the logging operation, exposing some rock and bare soil. At the time of this study, grass and forb growth was good on this disturbed soil.

The site on watershed 17 had been severely thinned, leaving only even-aged pine 14-24 inches in diameter and some Gambel oak. The slash had been windrowed and covered approximately $15 \%$ of the area. The rows were spaced about 50 feet apart. Ground disturbance during logging stimulated understory vegetation growth, especially common mullein and other invading species.

Watershed 11 was clearcut, and all slash was removed or burned. A stand of intermediate wheatgrass, blue grama, bottlebrush squirreltail, and other grasses provided food and ground cover for rodents. This site contained $35 \%$ surface rock. Many large rocks had been exposed and dislodged during logging, creating good rodent habitat. Smaller rock was probably brought to the surface by frost heaving.

The site on watershed 8 was heavily forested with pine. Many trees were in the medium size classes, which are not common on the Beaver Creek Watershed. Thick litter and numerous fallen logs covered the ground. Grass and forb growth was good in the more open areas but poor in the dense pine stands.

The trap site on watershed 10 included about two-thirds pine and one-third juniper, the approximate ratio of these types on this watershed. The pine was generally young with few trees more than 12 inches in diameter. The ground under the pines was covered by a shallow litter layer with very few fallen logs or rock. The juniper was generally in rocky ground with little topsoil. A rocky slope bordered the northern edge of the trap site. Understory vegetation was sparse.

\section{Methods and Materials}

\section{Live Trapping}

A live trap grid developed by Cockrum and Vaughan (1971) and used on their Sonoran Desert validation studies in southern Arizona was chosen for this study. The square grid contained 196 live traps in 14 rows of 14 traps each spaced 33 feet apart. Trap spacing was based on the radius of the home range of the brush mouse, the least mobile species probably present on the watershed. Spacing between traps was set at 33 feet to expose animals to at least four traps and, therefore, provide data to determine their home range.

From two to four potential trap sites for each watershed were chosen from a topographic map and then inspected on the ground. To minimize intersite variability, all sites were chosen on south to west facing aspects with less than $10 \%$ slope. Manpower and time limitations prevented study of more than one site per watershed; therefore the site most representative of the overall watershed habitat was selected for trapping. 
Table 1.-Descriptions and treatments of the watersheds used for the rodent study

\begin{tabular}{|c|c|c|c|c|c|}
\hline $\begin{array}{c}\text { Watershed } \\
\text { number }\end{array}$ & Acres $^{1}$ & $\begin{array}{c}\text { Elevation' } \\
\text { (feet) }\end{array}$ & $\begin{array}{l}\text { Trees } \\
\text { per acre }\end{array}$ & $\begin{array}{c}\text { Basal area } \\
\text { per acre }\end{array}$ & Treatment \\
\hline 13 & 910 & 7,200 & 898 & 98 & $\begin{array}{l}\text { This is an untreated watershed } \\
\text { covered with mixed ponderosa pine. } \\
\text { Two rocky canyons extend into the } \\
\text { watershed and contain a mixture of } \\
\text { pine and juniper. }\end{array}$ \\
\hline 14 & 1,349 & 7,300 & ${ }^{3} 726$ & 54 & $\begin{array}{l}\text { A strip, shelterwood cut was done in } \\
1970-71 \text {. One-third of the watersined } \\
\text { was cleared in irregular, } 30-90 \text { feet } \\
\text { wide strips, and two-thirds were thin- } \\
\text { ned to } 80 \text { square feet basal area per } \\
\text { acre. Slash from the leave strips was } \\
\text { partially piled and burned. The pine } \\
\text { was cut so as to leave mostly } 14-\text { to } \\
24-i n c h \text { trees. Small Gambel oak was } \\
\text { left in the strip cuts. }\end{array}$ \\
\hline 17 & 299 & 7,040 & ${ }^{3} 1,082$ & 30 & $\begin{array}{l}\text { In } 1969 \text { the pine was heavily thinned } \\
\text { leaving } 30 \text { square feet basal area per } \\
\text { acre of 14- to } 24 \text {-inch trees. All } \\
\text { juniper and large Gambel oak were } \\
\text { removed. The slash and windrowed } \\
\text { perpendicular to the drainage } \\
\text { pattern. }\end{array}$ \\
\hline 11 & 188 & 6,610 & 0 & 0 & $\begin{array}{l}\text { This watershed was cleared and } \\
\text { planted in grass in 1958. Heavy } \\
\text { stands of vegetation, primarily } \\
\text { intermediate wheatgrass (Agropyron } \\
\text { intermedium), blue grama (Bouteloua } \\
\text { gracilis), and bottlebrush squirreltail } \\
\text { (Sitanion hystrix) built up from } \\
\text { 1958-66. From } 1967-71 \text { spring and fall } \\
\text { grazing removed one-half of the } \\
\text { perennial grass growth. }\end{array}$ \\
\hline 8 & 1,802 & 7,360 & ${ }^{3} 473$ & ${ }^{3} 98$ & $\begin{array}{l}\text { This watershed was untreated during } \\
1972-73 \text { research. In spring } 1974 \text {, the } \\
\text { area was thinned with a shelterwood- } \\
\text { seed tree cut. }\end{array}$ \\
\hline 10 & 571 & 6,880 & ${ }^{3} 635$ & ${ }^{3} 75$ & $\begin{array}{l}\text { This watershed was uncut pine and } \\
\text { juniper during the } 1972-73 \text { research. } \\
\text { In } 1974 \text {, one-third of the area was cut } \\
\text { in small clearings (less than } 10 \text { acres) } \\
\text { and the slash was piled. The re- } \\
\text { maining timber was thinned. }\end{array}$ \\
\hline
\end{tabular}

'Price (1967)

${ }^{2}$ Ffolliott (1974)

${ }^{3}$ Pretreatment data

Rodents were captured in 4- by 4- by 10 -inch screen and metal live traps. A mixture of peanut butter and rolled oats was used as bait. Traps were checked at dawn and dusk and rebaited every 3 days or as needed. Captured animals were marked by toe clipping, weighed, sexed, and released.

During summer and fall of 1972, trapping was conducted on the untreated control, silviculturally improved, big game habitat improvement, and clearcut and range reseeded watersheds (table 2). Each grid was run for a 10-day interval followed by periodic 2-day checks. This resulted in the watersheds receiving from 14 to 19 days of trapping. In summer 1973, the control, irregular strip shelterwood, and severely thinned (treated 1969) watersheds each received 18 consecutive days of live trapping. This live trapping provided data on species, density, and distribution in the different habitats on each watershed. However, a 
severe winter between these summers significantly reduced the rodent populations. Since more of certain species were killed than others, rodent population densities could not be compared among watersheds not trapped each year.

During summer 1974, each of the watersheds except the big game habitat improvement was trapped for 5 consecutive days (table 2). Therefore, rodent population densities were compared between watersheds based primarily on the 1974 data. The big game habitat watershed was being logged in 1974 and the fallen trees and piled slash prevented trapping. Densities for this area were based on the species density ratio between this watershed and the control for 1972. For example, the brush mouse population density on the control in 1974 dropped to $66 \%$ of the 1972 level (from 29 to 19). Therefore, the 1974 population density of this species on the big game habitat watershed was calculated as $66 \%$ of its 1972 density.

In 1975, the silviculturally improved, big game habitat, and control watersheds were trapped for 5-day periods in summer and fall to determine rodent population densities after timber harvesting.

Density estimates were made by dividing the actual number of a species caught by the percentage of the trap grid in which it was found. For example, brush mice were caught on the control live trap grid ( 4.17 acres), but since the species was found in only $23 \%$ of this acreage, its density was estimated by dividing 19 by 0.96 acres rather than by the entire 4.17 acres. The actual number

Table 2. Dates of live trapping for each watershed

\begin{tabular}{|c|c|c|c|}
\hline Watershed & 1972 & 1973 & 1974 \\
\hline $\begin{array}{l}\text { 13-Control } \\
\text { watershed }\end{array}$ & $\begin{array}{l}\text { June } 18-27 \\
\text { July } 24-26 \\
\text { Aug. } 2-3 \\
\text { Aug. } 30-31\end{array}$ & $\begin{array}{l}\text { June } 21 \text { - } \\
\text { July } 8\end{array}$ & $\begin{array}{l}\text { May } 29 . \\
\text { June } 2\end{array}$ \\
\hline $\begin{array}{l}11-\text { Clearcut and } \\
\text { range reseeded }\end{array}$ & $\begin{array}{l}\text { July } 23- \\
\text { Aug. } 2 \\
\text { Sep. } 21-28\end{array}$ & & June 3.7 \\
\hline $\begin{array}{l}10-\text { Big game } \\
\text { habitat } \\
\text { improvement }\end{array}$ & $\begin{array}{l}\text { July } 8-17 \\
\text { Aug. } 5-6 \\
\text { Oct. } 22-23\end{array}$ & & \\
\hline $\begin{array}{l}\text { 8-Silviculturally } \\
\text { improved }\end{array}$ & $\begin{array}{l}\text { July 6-15 } \\
\text { Aug. } 10-11 \\
\text { Aug. } 30-31\end{array}$ & & June 4-8 \\
\hline $\begin{array}{l}\text { 14-Irregular strip } \\
\text { shelterwood }\end{array}$ & & $\begin{array}{l}\text { June } 21 \\
\text { July } 8\end{array}$ & $\begin{array}{l}\text { May } 29 \text { - } \\
\text { June } 2\end{array}$ \\
\hline $\begin{array}{l}\text { 17-Severely } \\
\text { thinned }\end{array}$ & & $\begin{array}{l}\text { July } 24- \\
\text { Aug. } 10\end{array}$ & June $8-12$ \\
\hline
\end{tabular}

of animals caught was used to determine density rather than a calculated total population because small sample sizes with few recaptures generally prevented precise population estimates.

The changes in rodent populations caused by the watershed treatments were evaluated in terms of both density and biomass. Weights for each species on each watershed were averaged, and the averages for species common to several watersheds were compared. Since averages did not differ significantly between watersheds, all weights for each species were pooled to provide an average for total biomass calculations.

Observations of areas sought by deer mice when released from live traps showed they consistently used stumps and downed logs for escape cover. Therefore a correlation was run between deer mice and downed logs more than 6 inches in diameter available for cover. Windrowed slash was not included in the square footage measurement because it consisted primarily of smaller diameter material.

\section{Snap Trapping}

Snap trapping was used to obtain specimens for stomach analysis and to provide additional data on species distribution. Museum specials and rat traps were distributed at 10-yard intervals along existing timber inventory transects. These parallel transect lines were spaced 12 to 20 chains apart throughout the watersheds. Trapping was conducted in August and September 1972 and June through August 1973. Fall and winter trapping was unsuccessful because rain and snow triggered or covered the traps. From 50 to 200 traps were set each night. Trapping continued until approximately 20 of the most common species were captured on each watershed.

\section{Gopher Census}

Pocket gophers were censused by mound counts using a modification of Howard's (1961) method during August 14-17, 1973. Mound groups were counted in a 13.2-foot-wide strip along the existing timber inventory transects. When a fresh mound was found, no additional mounds were counted for 5 yards. This method assumed a mound group covering a maximum area of 25 square yards and one animal per mound group. Therefore, a direct estimate of the gopher population could be made.

\section{Vegetation Analysis}

The different components of the ground cover on the watersheds were measured using a mod- 
ification of Daubenmire's (1959) method during summer 1972. Ground cover was classed as percent grass, forb, litter, bare soil, and rock to show any significant differences between the watersheds. The percent grass and forb cover also indicated the relative abundance of food available to rodents. An 8 - by 20 -inch area was measured at each of the 145 to 195 inventory points already established on the existing timber inventory lines on the watersheds. Percent cover for grass and forbs was based on stem area at ground level.

\section{Stomach Analysis}

Food preferences during summer were determined by microscopic analysis of their stomach contents based on the method described by Storr (1961) and Anthony (1972). Most plant species have a characteristic epidermal cuticle design by which they can be identified. Most cuticles are not affected by the digestive process and, therefore, provide an accurate means of identifying plant species either in the stomach or in feces.

A reference collection of known cuticle samples was needed for this technique. Common plant species on the Beaver Creek watersheds were collected and dried during summer field work and later made into reference slides. Three slides were made for each species: one of flower or seed material, one from leaves and stem, and one from the root system.

Stomachs of rodents collected by snap trapping were preserved in $10 \%$ formalin until ready for processing. The stomach contents were then boiled in 5 to $10 \mathrm{ml}$ of concentrated nitric acid until the plant cuticles separated. These cuticle fragments were then compared with the known cuticle samples.

\section{Habitat Preferences}

Ten species of rodents were captured on the Beaver Creek watersheds during trapping in 1972-74. These included the deer mouse, brush mouse, white-throated woodrat, Mexican woodrat, cliff chipmunk, gray-collared chipmunk, golden-mantled ground squirrel, rock squirrel, and the Mexican vole.

The rock squirrel was too large to be consistently caught in either the live or snap traps and, therefore, will not be discussed as part of this study. Also, no further discussion will be made of the Mexican vole because of its apparent rarity on the study areas.

\section{Deer Mouse}

The deer mouse was the most characteristic species of the ponderosa pine ecosystem. This species was captured on all six watersheds and was present in every habitat type, although often in low densities. The deer mouse was the principal species found in pure stands of pine, mixed pinejuniper, and in open grassland. This was consistent with the habitat described for deer mice in other studies (Geluso 1971, Jameson 1951 and 1952, Gashwiler 1959 and 1970, Tevis 1956).

A near perfect correlation was found between the population density of deer mice on the grids and the square feet of stumps and downed logs available for hiding and nesting places (fig. 1). The mice consistently hid in the larger logs or stumps. The fallen logs created still air spaces which served as good nesting sites. Nests were also found inside bark which had separated from stumps and logs. Mice were rarely seen entering holes in the ground, and very few dens of this type were found during the study.

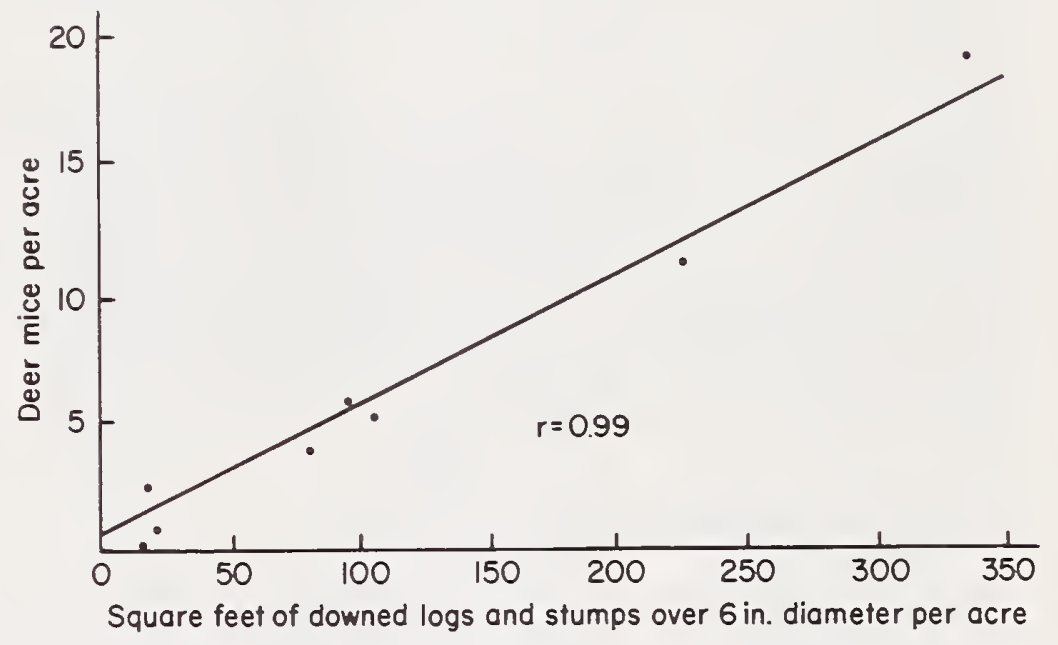

Figure 1.-Response of deer mouse density to increased ground debris in the pine habitat.

The population density of deer mice increased from two mice per acre in areas where debris measured less than 25 square feet per acre to 19 mice per acre when the debris increased to 335 square feet per acre.

Correlation between deer mouse population density and trees per acre, basal area per acre, site index, and percent grass, forbs, litter, rock, and bare soil on each trap site were not significant.

\section{Brush Mouse and Woodrat}

The habitat preferred by brush mice, whitethroated woodrats, and Mexican woodrats was almost identical. All three species were found in very high density along rock ledges and slides. Studies by Brown (1969), Jameson (1951 and 
1952), and Geluso (1971) agree that these species prefer habitat with rock cliffs and brush-rock slopes.

Along these rocky slopes, brush mouse population density ranged from 20 per acre in mild years to 6 per acre after a harsh winter. Woodrat populations varied from 2 to 10 per acre. Eightyfive percent of the recaptures for these species were within 60 feet of the rock ledges, and no recaptures in open ponderosa pine stands were more than 210 feet from rocky cover.

Windrowed slash serves as an additional habitat type used by these species. However, the rodents were seldom captured far from the slash, and none of the marked animals were captured in an adjacent windrow only 100-130 feet away. Brush mouse and woodrat population densities in the slash varied from 4 to 12 per acre and 2 to 11 per acre, respectively.

These species were quite rare in the pure stands of pine and in the mixed pine-juniper areas. Their population densities were slightly higher (one per acre) in the open grassland, possibly because of the rocks and rock crevices found on the ground surface.

Both species of woodrat were consistently caught on the rocky slopes, but only the Mexican woodrat was captured in the windrowed slash. Also, the few individuals found in the pure pine were all Mexican woodrats. Therefore, it appears that the Mexican woodrat may be more adaptable to different habitats than the white-throated woodrat.

\section{Southern Pocket Gopher}

Pocket gopher mounds were found on all six watersheds and in most habitat types, but this species was only common on the silviculturally improved watershed. There the gophers found deep soil with abundant grasses and forbs for food. A significant correlation $(r=0.67$, d.f. 4 , $p<0.10$ ) was found between number of gophers and percent surface rock, which served as an indicator of top soil depth. Davis et al. (1938) and Miller (1948) found that gophers favored deep soils.

Measurable gopher populations were only found on three watersheds. The pretreated silviculturally improved watershed had a density of 0.22 gophers per acre, and the irregular strip shelterwood and severely thinned watersheds had populations of 0.04 to 0.05 gophers per acre. Studies have found that the size of gopher territories varies considerably with habitat type and population density (Hansen and Remmenga 1961) and that densities may reach 8 to 10 gophers per acre (Ingles et al. 1949). Since gopher population densities on Beaver Creek did not exceed 0.22 per acre, and generally were much less, this species appeared to be relatively unimportant in this ecosystem.

\section{Chipmunk}

Since trap success for both species of chipmunks was less than $1 \%$ on all areas, habitats used and density estimates were based on observations made during the study.

The cliff chipmunk was consistently observed and occasionally captured in the area where the pine had thinned, but was seldom seen in the untreated pine stands. The gray-collared chipmunk was only seen or captured in dense stands of fairly mature pine and usually at the higher elevations.

Studies by J. H. Brown (1971), Heller (1971), and Sheppard (1971) showed that interspecific competition and altitudinal zonation played key roles in determining chipmunk distribution and population density. Brown (1971:305) stated:

"E. dorsalis, the more aggressive and more terrestrial species, chases umbrinus from those areas where the trees are so widely spaced that umbrinus must flee on the ground. The competitive advantage immediately shifts to the more social and arboreal umbrinus when the trees are sufficiently large and dense that their branches interlock. In these habitats umbrinus readily escapes dorsalis by fleeing through the trees over routes that the more aggressive species cannot follow. In such situations the aggressive nature of dorsalis actually becomes competitively disadvantageous because the more social umbrinus is so numerous that dorsalis wastes a great deal of time and energy on fruitless chases."

This statement seems to describe observations of cliff and gray-collared chipmunks in the mature forest on the silviculturally improved watershed. Observations of aggression between the two species showed that the cliff chipmunk was dominant and that the gray-collared chipmunk sought protection in the trees when confronted.

The gray-collared chipmunk was only found in the most mature of the forests studied, and also lived at the highest average elevation $(7,360$ feet). On a nearby watershed (average elevation 7,300 feet), where the pine had been thinned, many cliff chipmunks were found, but the gray-collared chipmunk was not present. However, the graycollared chipmunk was seen in other nearby stands which contained a wide mixture of pine age classes but always at high elevations. Lowe 
(1975) found that gray-collared chipmunks were abundant in the mature forests west of Flagstaff at elevations between 7,400 and 8,000 feet, but that their density decreased as the forest canopy was opened. He found no cliff chipmunks on any of his study sites.

Therefore, it appears that altitudinal zonation separates these species at about 7,300 feet. Along this boundary, the cliff chipmunk dominates the more open forest stands, while the gray-collared is more abundant in the more dense forests.

Population densities of cliff chipmunks varied widely from about 1 per 20 acres in dense pine stands to about 1 per 2 acres in thinned pine stands and along the rock ledges inhabited by woodrats and brush mice.

Gray-collared chipmunk population densities were calculated at 2 per acre in May and 5 per acre in August by another study in Coconino County (Clothier 1969). Observations on Beaver Creek supported these estimates.

\section{Golden-mantled Ground Squirrel}

The golden-mantled ground squirrel was abundant in the same habitat where the gray-collared chipmunk was found. The dense, mature forest on the silviculturally improved watershed appeared to be the preferred habitat, but this species was also seen in more open stands but only at high elevations. Lowe et al. ${ }^{3}$ found that ground squirrels were abundant in both dense and open forests above 7,400 feet elevation. Therefore, altitudinal zonation appears to limit the distribution of ground squirrels on the Beaver Creek watersheds. Density was estimated at 1 per 4 acres in the denser forests and 1 per 20 acres in more open stands.

\section{Timber Harvesting Effects on. Rodent Populations}

Three basic habitat types were present in the uncut forest: pure pine, mixed pine-juniper, and rock slopes. Since the treatments involved manipulation of tree density and slash removal, only the first two habitat types were affected. The rock slopes contained high rodent populations, but pretreatment and post-treatment densities were comparable.

The results of each treatment were evaluated on the basis of changes in rodent population density, total biomass, and species diversity comparing populations to the control watershed

${ }^{3}$ Lowe, Philip O., Peter F. Ffolliott, Warren P. Clary, and E. L. Fitzhugh. 1975. Effect of a wildfire on rodent populations in Arizona ponderosa pine. Unpub. rep. Watershed Dep., Univ. Ariz. pine type during the study period. Population changes were assessed for each habitat type and then combined to provide an average density and biomass for the entire watershed.

\section{Control Watershed}

The untreated control contained two habitat types. Approximately $85 \%$ of the watershed was covered by pine stands; the other $15 \%$ was rocky canyons.

The pine stands were very poor rodent habitat, because there were few downed trees or little debris to provide cover, and few grasses or forbs to provide food. Rodent population density was calculated at only 1.3 animals per acre, all deer mice. The watershed was too low for ground squirrels or gray-collared chipmunks, and the dense forest excluded cliff chipmunks. Rocky soil made most areas unfavorable for pocket gophers. Biomass for this habitat was 16.5 grams per acre. Figure 2 shows how these density and biomass estimates rank with the other watersheds.

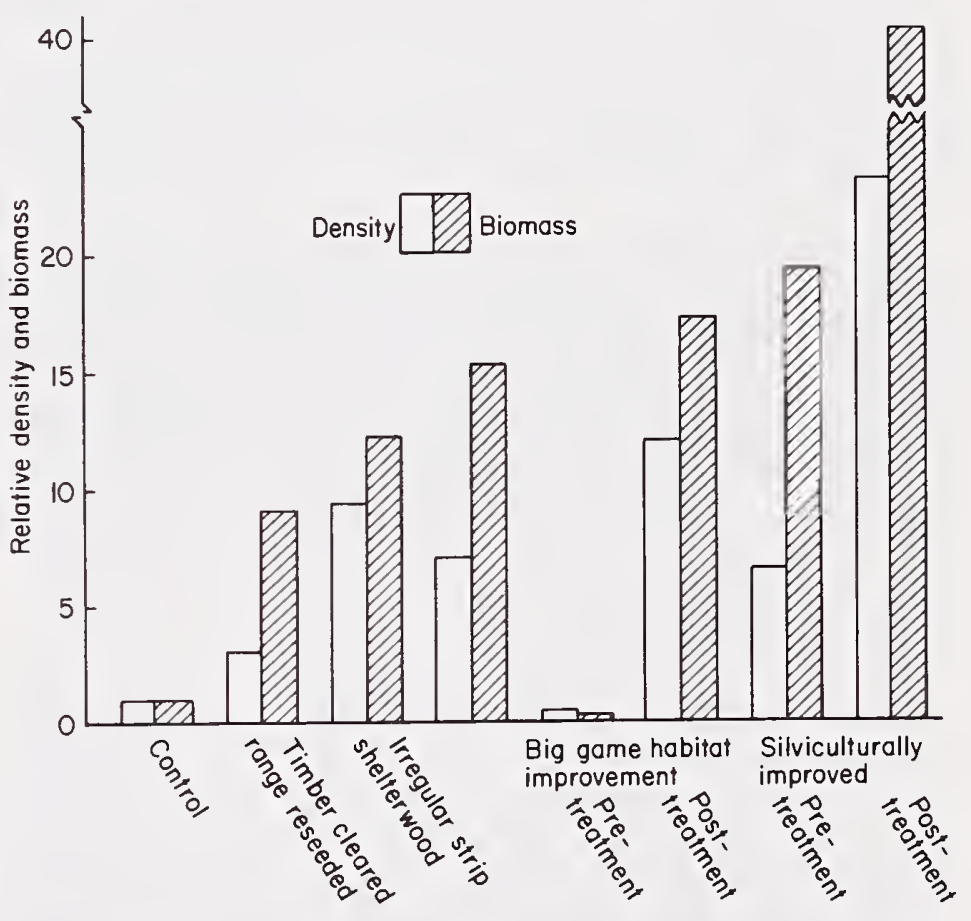

Figure 2.-Rodent density and biomass relative to the control watershed. Base levels on the control watershed were 1.25 animals per acre for density and 16.54 grams per acre for biomass.

The rock canyons proved to be excellent habitat for several species. There were 19.8 brush mice per acre, 2.1 woodrats per acre, 0.5 cliff chipmunks per acre, and 0.1 deer mice per acre for a total of 22.5 animals per acre. The brush mouse was most important in terms of both density and biomass but the woodrat added significantly to the total biomass. The average density for the entire watershed was 4.4 animals per acre and the biomass was 134.1 grams per acre. 


\section{Irregular Strip Shelterwood}

This watershed bordered on the east edge of the control watershed and, prior to treatment, the areas were similar in tree size and density. About $95 \%$ of the watershed was covered by pine which was moderately thinned, and the other $5 \%$ consisted of scattered rock outcroppings.

Thinning the pine left many cull logs and large branches scattered on the area. Some of the slash was not piled, and much of that which was piled was not completely burned. The disturbed soil also stimulated forb growth. These conditions created excellent habitat for deer mice. This species had a population density of 11.0 per acre and a biomass of 163.5 grams per acre. These figures show a $782 \%$ increase compared to the deer mouse population on the control watershed. The pine also contained small populations of pocket gophers which were probably attracted by the abundant forbs, and Mexican woodrats which were drawn to the unburned slash. Thinning the pine raised the cliff chipmunk population density to the level close to that found in the open rocky canyons of the control watershed. Density in the thinned pine increased $830 \%$ to 11.6 animals per acre, and biomass increased $1,133 \%$ to 203.9 grams per acre.

The scattered rock outcroppings were not extensive enough to provide a significantly different habitat type, and most densities were the same as those found in the surrounding pine. The total population density of animals throughout the watershed was 11.7 animals per acre and total biomass was 215.5 grams per acre.

\section{Severely Thinned}

The pine on this watershed was severely thinned, and the slash was piled in parallel rows. About $80 \%$ of the area was covered by pine and the other $20 \%$ by windrowed slash. Pretreatment timber inventory indicated this watershed originally had a more dense forest than the control watershed.

The thinned pine, with a density of 5.3 animals per acre was good habitat for deer mice. Cliff chipmunk population density was 0.7 per acre, which was the highest for this species on any of the watersheds. A small population of pocket gophers also was present. These figures indicate a rodent population density $383 \%$ higher than that found on the control watershed. Biomass (104.6 grams per acre) increased $533 \%$ over that of the control.

The windrowed slash was good habitat for brush mice and Mexican woodrats with respective population densities of 12.1 and 2.4 animals per acre. Since these species were only incidental inhabitants of other thinned or unthinned pine stands, it appears that the slash created "fingers" of new habitat which allowed brush mice and Mexican woodrats to extend their range into the pine. Deer mouse and cliff chipmunk population densities in the windrowed slash were similar to those found in the pine.

Total rodent population density for the watershed was 8.9 animals per acre, and total biomass was 254.3 grams per acre. The most significant aspect of this treatment was the increased species diversity resulting from the windrowed slash. The brush mice and Mexican woodrats comprised $32 \%$ of the total rodent density and $49 \%$ of the biomass.

\section{Clearcut and Range Reseeded}

This conversion from pine to grassland represents the extreme in forest manipulation. About $95 \%$ of the habitat was grassland and $5 \%$ rock outcroppings.

Deer mouse population density measured 2.6 animals per acre-a $111 \%$ increase over the control. Few downed logs, which normally provide nest sites for deer mice, were available, but the machinery used in the logging operation had dislodged many large rocks near the ground surface, creating crevices which served as alternate nest areas.

Additionally, the loss of the tree roots, which stabilized the soil, allowed frost heaving to bring smaller subsurface rock to ground level. Consequently, in 1973, rock covered $35 \%$ of the ground surface. This provided habitat for low densities of brush mice and woodrats in the grassland $(0.5$ and 0.7 animals per acre, respectively). The population density of both species increased to 1.0 per acre in the rock outcroppings.

Rodent population density in the grassland was $192 \%$ greater than the control (3.7 animals per acre) and biomass increased $799 \%$ to 148.7 grams per acre. The slightly higher densities in the rock outcroppings resulted in a total density on the watershed of 3.9 animals per acre and a biomass of 159.2 grams per acre.

\section{Big Game Habitat Improvement}

Three habitat types were present on this watershed: pine covered $60 \%$ of the area; mixed pine and juniper covered $30 \%$; and the remaining $10 \%$ was comprised of rock slopes.

Before treatment in 1974 , the pine stands contained little cover for rodents and supported only about 0.1 animal per acre. The mixed pine-juniper type provided neither the downed logs to attract 
deer mice nor the surface rock to support brush mice, and, therefore, contained only 0.2 animal per acre (12\% of the density in the control forest). Biomass was equally low, measuring 2.6 grams per acre.

The rock slopes averaged 10.8 brush mice per acre, 3.9 white-throated woodrats per acre, and low population densities of deer mice and cliff chipmunks. The brush mice were the most numerous species, but their biomass was only about one-half that of the woodrats.

The watershed averaged 1.6 animals per acre and supported a biomass of 84.3 grams per acre. Both the density and biomass found there were the lowest of all the watersheds.

This watershed was logged in 1974. The prescription calls for a thinning of the pine and creation of scattered openings up to 10 acres. The slash was piled in the clearings. The scattered logs left after treatments and the slash piles provided the necessary habitat for deer mice to increase to $600 \%$ of the density found on the control. The piled slash also allowed Mexican woodrats and brush mice to disperse into the pine habitat. In addition, the treatment caused an influx of pinyon mice, not previously found on this watershed. Their population density nearly equalled that of deer mice. The net effect of this treatment was a $4,800 \%$ increase in density and a $11,500 \%$ increase in biomass in the pine habitat. Rodent populations on the rock slopes did not change after treatment of the pine habitat.

\section{Silviculturally Improved}

This watershed had a more mature forest than that found on the control and was higher than the other study a reas.

Before treatment in 1974 , seven species were found in the pine stands. Two of these, graycollared chipmunks and golden-mantled ground squirrels, were not present on any other watershed. The deer mouse was the most numerous species with a population density of 3.8 per acre. However, the gray-collared chipmunk was almost as prevalent with 3.0 per acre. The latter species contributed 184.7 grams per acre, which accounted for $58 \%$ of the pine type biomass of 320.6 grams per acre. Small populations of brush mice, Mexican woodrats, cliff chipmunks, ground squirrels, and pocket gophers increased the total rodent population density to 7.9 animals per acre (a $532 \%$ increase over the control). Excluding the two species not found in the pine on the control watershed because of altitudinal zonation, the density was still $286 \%$ above the control level. These figures indicated that more mature pine stands supported a greater population density and diversity of rodents.

The silviculturally improved watershed was logged in 1974. The prescription called for a moderate thinning of the forest and removal of the slash. However, when the study area was trapped in 1975, most of the slash still remained scattered on the ground. This slash created ideal habitat for deer mice which increased in population density to $650 \%$ of the pretreatment level. The population density of other species remained unchanged following treatment. Therefore, the net effect of the treatment was a $270 \%$ increase in population density (caused entirely by deer mice) and a $100 \%$ increase in total rodent biomass.

\section{Food Habits}

A review of the literature on food habits of rodents showed the great adaptability of the order Rodentia. Ample evidence demonstrates that a species may feed primarily on insects in one habitat while eating only vegetation in another location. This supports the generally accepted opinion that rodents are basically opportunistic, feeding on whatever is most abundant.

Jameson (1952) described the diet of deer mice as consisting mostly of forb and grass seeds in the summer and primarily tree seeds in the winter. Hamilton (1941) found eastern mice fed on insects, vegetation and fruits during the summer and insects and seeds in the winter. Tevis (1956) listed grasses and forbs as comprising $82 \%$ of the summer diet of ground squirrels with the other $18 \%$ being insects. He found that chipmunks were more insectivorous, eating $22 \%$ insects and $78 \%$ seeds and vegetation. Many studies showed pocket gophers to be very dependent on forbs (Miller 1964, Vaughan 1967, Ward and Keith 1962, and Tietjen et al. 1967) while other articles stated grasses and pine roots were the staple items (Dingle 1956, Meyers and Vaughan 1964). Differences in habitat and food availability probably account for these variations.

The food habits portion of this study was based on the assumption that the rodents would be opportunistic in their feeding habits. Forty-three of the most common grasses, forbs, trees, and shrubs were collected on the watersheds, and reference slides showing flowers and seeds, leaves and stems, and root samples were made for each plant.

A total of 185 animals were collected in approximately 5,000 trap nights. Chipmunks and ground squirrels were very difficult to trap; therefore, an 
additional 23 of these species were collected with a shotgun to improve the sample size.

Estimates of the vegetative ground cover on the watersheds showed $57 \%$ was grass and $43 \%$ was forbs. No estimates were made of seed material present in the ground litter or percentage of ground cover occupied by tree and shrub seedlings. Young' $\mathrm{s}^{4}$ initial studies of insect population density and biomass on the Beaver Creek watersheds showed that both values decreased as the intensity of treatment increased.

The average diet of the Beaver Creek rodents was very consistent for all species except pocket gophers. Insects comprised $15 \%$ by volume of the total diet and vegetation or unknowns $85 \%$ (fig. 3). The estimate for insects is probably low, because only the legs and exoskeleton were readily identified. Most of the soft parts of the insects were either destroyed by digestion or were not recognized during the analysis. Forbs comprised 58\%, grasses $16 \%$, and trees less than $1 \%$ of the total volume. Unknowns made up $11 \%$ of the diet. Analysis of deer mouse diet showed some vari-

${ }^{4}$ Young, R. M. 1973. Relative insect density and biomass. p. 17-20. In Beaver Creek evaluation project progress report. Unpubl. rep. U.S. Dep. Agric., For. Serv., Rocky Mt. For. and Range Exp. Stn., For. Sci. Lab., Flagstaff, Ariz.

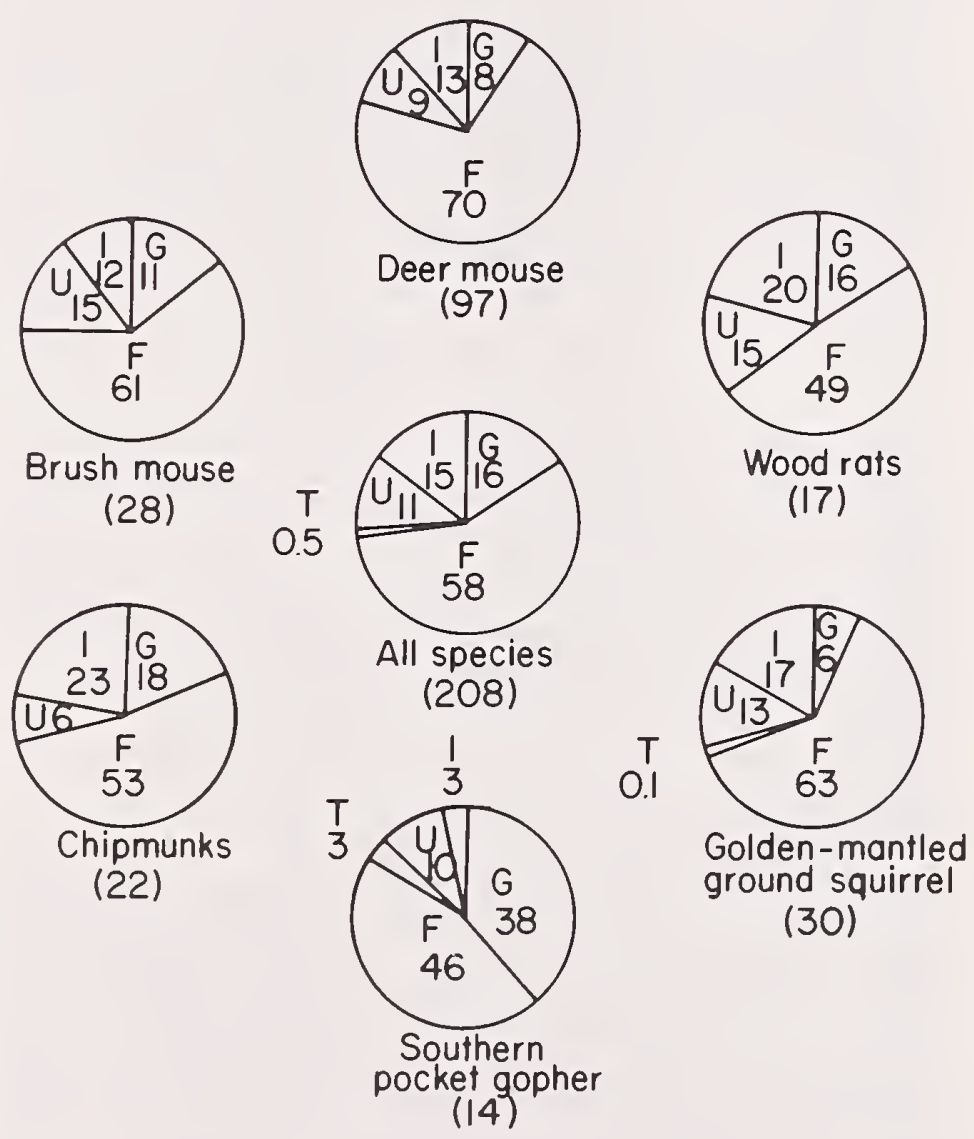

Figure 3.-Percentage of food types found in rodent stomachs collected during summers of 1972-73. Numbers in parentheses indicate sample size; letters stand for grass $(G)$, forbs $(F)$, tree $(T)$, insects $(I)$, and unknown (U). Numbers with letters indicate percent of total. ability in plant species eaten on treated versus untreated watersheds but the averages for percent grasses, forbs, and trees were not significantly different. Therefore it appears that the watershed treatments did not alter the rodents' diet. Analysis of the diet for other species between treated and untreated watersheds was not practical because of small sample sizes.

Although forbs made up $43 \%$ of the ground cover, they provided a significantly higher proportion of the average diet $\left(\mathrm{x}^{2}=4,269,4\right.$ d.f., $\mathrm{p}<0.05$ ). Groundsel dominated the diet of all rodents, accounting for $25 \%$ of the vegetation eaten. Other important forbs were goldenrod, Arizona agoseris, spreading fleabane, goldenweed, and white sweetclover.

Since the average rodent had an average of 3.8 species in its stomach when captured, it appears that each animal was feeding heavily from a small number of plants. When stomachs were opened in the lab for treatment, the contents were usually layered into different colors and textures of material. Each layer was probably particles of a single plant species. Seed heads and flowers accounted for about $75 \%$ of the diet, with leaves and stems providing $25 \%$. Only pocket gophers ate root material.

In summer, rodents ate relatively few ponderosa pine seeds and seedlings on Beaver Creek. Seedlings comprised only 3\% of pocket gopher diet, and seeds were an incidental item in the diet of several species. Seeds which are normally dropped in the fall may be eaten during other seasons. Pocket gophers may depend more heavily on pine seedlings during fall and winter when forbs and grasses are less abundant, but because of the low population density of pocket gophers in the study area, there should be little damage to pine reproduction.

\section{Literature Cited}

Anthony, Robert G. 1972. Ecological relationships between the Coues' white-tailed deer and the desert mule deer in southeastern Arizona. Ph.D. diss., 123 p., Univ. Ariz., Tucson.

Brown, Harry E. 1971. Evaluating watershed management alternatives. Am. Soc. Civil Eng. J. Irrig. and Drainage Div. 96(IR1):93-108.

Brown, Harry E., Malchus B. Baker, Jr., James J. Rogers, Warren P. Clary, J. L. Kovner, Frederick R. Larson, Charles C. Avery, and Ralph E. Campbell. 1974. Opportunities for increasing water yields and other multiple use values on ponderosa pine forest lands. USDA For. Serv. Res. Pap. RM-129, 36 p. Rocky Mt. For. and Range Exp. Stn., Fort Collins, Colo. 
Brown, James H. 1971. Mechanisms of competitive exclusion between two species of chipmunks. Ecology 52(2):305-311.

Brown, Larry N. 1969. Reproductive characteristics of the Mexican woodrat at the northern limit of its range in Colorado. J. Mammal. 50(3):536-541.

Clothier, Ronald R. 1969. Reproduction in the graynecked chipmunk, Eutamias cinereicollis, general notes. J. Mammal. 50(3):642.

Cockrum, E. Lendell, and Terry Vaughan. 1971. Validation site. Mammal census. Desert Biome terrestrial validation studies, Sec. A3CE01. 13 p. Natl. Sci. Found. Int. Biol. Prog., Logan, Utah.

Daubenmire, Rexford. 1959. A canopy-coverage method of vegetational analysis. Northwest Sci. 33:43-64.

Davis, W. B., R. R. Ramsey, and J. M. Arendale, Jr. 1938. Distribution of pocket gophers (Geomys breviceps) in relation to soils. J. Mammal. 19(4):412-418.

Dingle, Richard W. 1956. Pocket gophers as a cause of mortality in eastern Washington pine plantations. J. For. 54(12):832-835.

Gashwiler, Jay S. 1959. Small mammal study in west-central Oregon. J. Mammal. 40(1):128-139.

Gashwiler. Jay S. 1970. Plant and mammal changes on a clearcut in west-central Oregon. Ecology 51(6):1018-1026.

Geluso, Kenneth N. 1971. Habitat distribution of Peromyscus in the Black Mesa region of Oklahoma. J. Mammal. 52(3):605-607.

Hamilton W. J., Jr. 1941. The food of small forest mammals in eastern United States. J. Mammal. 22(3):250-263.

Hansen, R. M., and E. E. Remmenga. 1961. Nearest neighbor concept applied to pocket gopher populations. Ecology 42(4):812-814.

Heller, H. Craig. 1971. Altitudinal zonations of chipmunks (Eutamias): Interspecific aggression. Ecology 52:312-319.

Howard, Walter E. 1961. A pocket gopher population crash. J. Mammal. 42(2):258-260.

Ingles, Lloyd G., Ronald Clothier, and Louis A. Crawford. 1949. Methods of estimating pocket gopher populations. J. Wildl. Manage. 13(4):311-312.

Jameson, E. W.. Jr. 1951. Local distribution of white-footed mice, Peromyscus maniculatus and $P$. boylei in the northern Sierra Nevada, California. J. Mammal. 32(2):197-203.
Jameson, E. W., Jr. 1952. Food of deer mice, Peromyscus maniculatus and Peromyscus boylei, in the northern Sierra Nevada, California. J. Mammal. 33(1):50-60.

Jennrich, R. I., and F. B. Turner. 1969. Measurement of non-circular home range. J. Theor. Biol. 22:227-237.

Lowe, Philip O. 1975. Effects of wildfire on wildlife populations in Arizona ponderosa pine. M.S. thesis, Univ. Ariz., Tucson.

Meyers, Gary T., and Terry A. Vaughan. 1964. Food habits of the plains pocket gopher in eastern Colorado. J. Mammal. 45(4):588-598.

Miller, Milton A. 1948. Seasonal trends in burrowing of pocket gophers (Thomomys). J. Mammal. 29(1):38-44.

Miller, Richard S. 1964. Ecology and distribution of pocket gophers (Geomyidae) in Colorado. Ecology 45(2):256-272.

Price, R. 1967. Possibility of increasing stream flow from forest and range watersheds by manipulating the vegetation cover-The Beaver Creek pilot watershed evaluation study. Int. Union For. Res. Org. XIV I.U.F.R.O.-Congress, V.1, Sect. 01-92-11.p. 487-504.

Schmidt, Wyman C. and Raymond C. Shearer. 1971. Ponderosa pine seed-For animals or trees? USDA For. Serv. Res. Pap. INT-112, 14 p. Intermt. For. and Range Exp. Stn., Ogden, Utah.

Sheppard, David H. 1971. Competition between two chipmunk species (Eutamias). Ecology 52(2):320-329.

Storr, G. M. 1961. Microscopic analysis of feces, a technique for ascertaining the diet of herbivorus mammals. Aust. J. Biol. Sci. 14:157-164.

Tevis, Lloyd, Jr. 1956. Effect of a slash burn on forest mice. J. Wildl. Manage. 20(4):405-409.

Tietjen, Howard P., Curtis H. Halvorson, Paul L. Hegdal, and Ancel M. Johnson. 1967. 2,4-D herbicide, vegetation, and pocket gopher relationships, Black Mesa, Colorado. Ecology 48(4):634-643.

Vaughan, Terry A. 1967. Food habits of the northern pocket gopher on shortgrass prairie. Am. Midl. Natur. 77(1):176-189.

Ward, A. Lorin, and James O. Keith. 1962. Feeding habits of pocket gophers on mountain grasslands, Black Mesa, Colorado. Ecology 43(4):744-749. 


\section{Appendix}

\section{Plants}

$\begin{array}{ll}\text { Alligator juniper } & \text { Juniperus deppeana } \\ \text { Blue grama } & \text { Bouteloua gracilis } \\ \text { Black dropseed } & \text { Sporobolus interruptus } \\ \text { Bottlebrush squirreltail } & \text { Sitanion hystrix } \\ \text { Flannel mullein } & \text { Verbascum thapsus } \\ \text { Gambel oak } & \text { Quercus gambelii } \\ \text { Intermediate wheatgrass } & \text { Apropyron intermedium } \\ \text { Muttongrass } & \text { Poa fendleriana } \\ \text { Ponderosa pine } & \text { Pinus ponderosa } \\ \text { Showy aster } & \text { Aster commutatus } \\ \text { Spreading fleabane } & \text { Erigeron divergens } \\ \text { Trailing fleabane } & \text { Erigeron flagellaris } \\ \text { Utah juniper } & \text { Juniperus osteosperma } \\ \text { Western ragweed } & \text { Ambrosia psilostachya }\end{array}$

Animals

Gray-collared chipmunk Eutamias cinereicollis Cliff chipmunk Uinta chipmunk Eutamias dorsalis Mexican vole Eutamias umbrinus Microtus mexicanus White-throated woodrat Neotoma albigula Miexican woodrat Neotoma mexicana Brush mouse Peromyscus boylei Deer mouse Pinyon mouse Peromyscus maniculatus Golden-mantled Peromyscus truei ground squirrel Rock squirrel Spermophilus lateralis Southern pocket gopher Thomomys umbrinus 


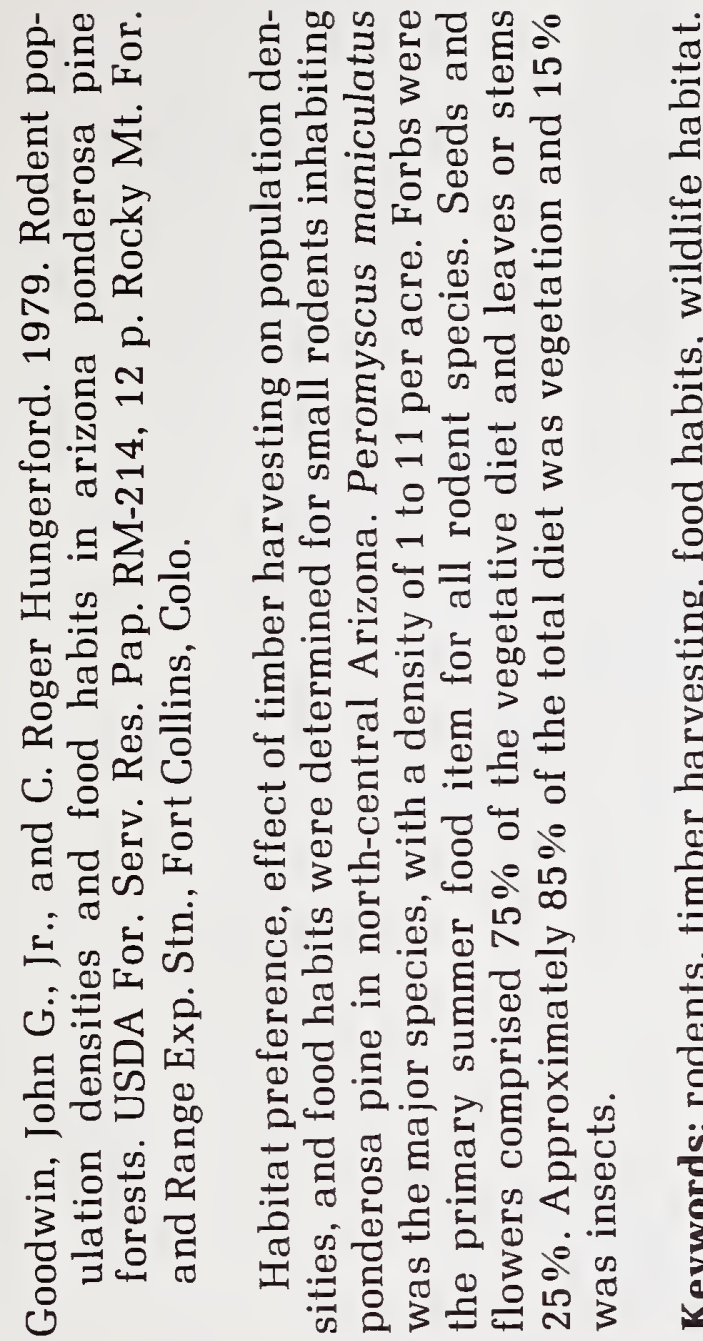

客.

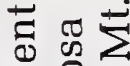

宅离

के

ô

ำ ำ

b. ㄱ.

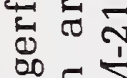

$\Xi \Xi \sum_{\infty, 1}^{1}$

北

造䒕

平

व

串㱐

: तु

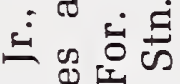

ง.

등

ป

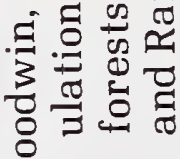

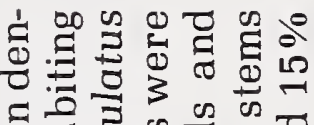

$\frac{\pi}{0}$

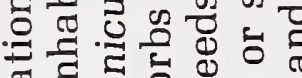

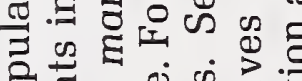

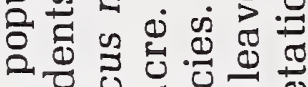

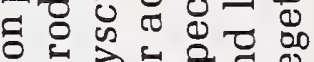

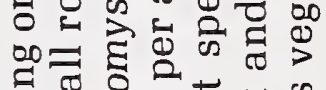

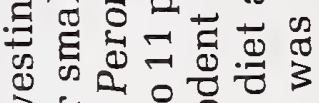

ว

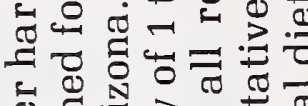

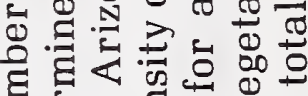

ॠण

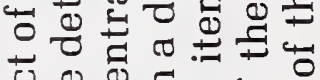

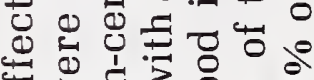

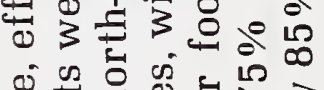

गे

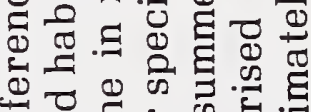

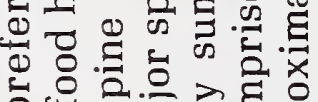

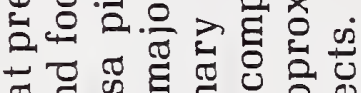

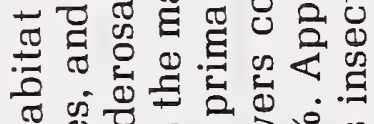

ठำ

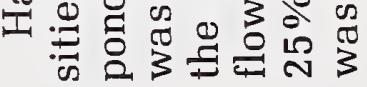

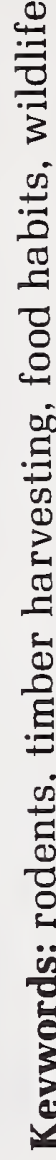

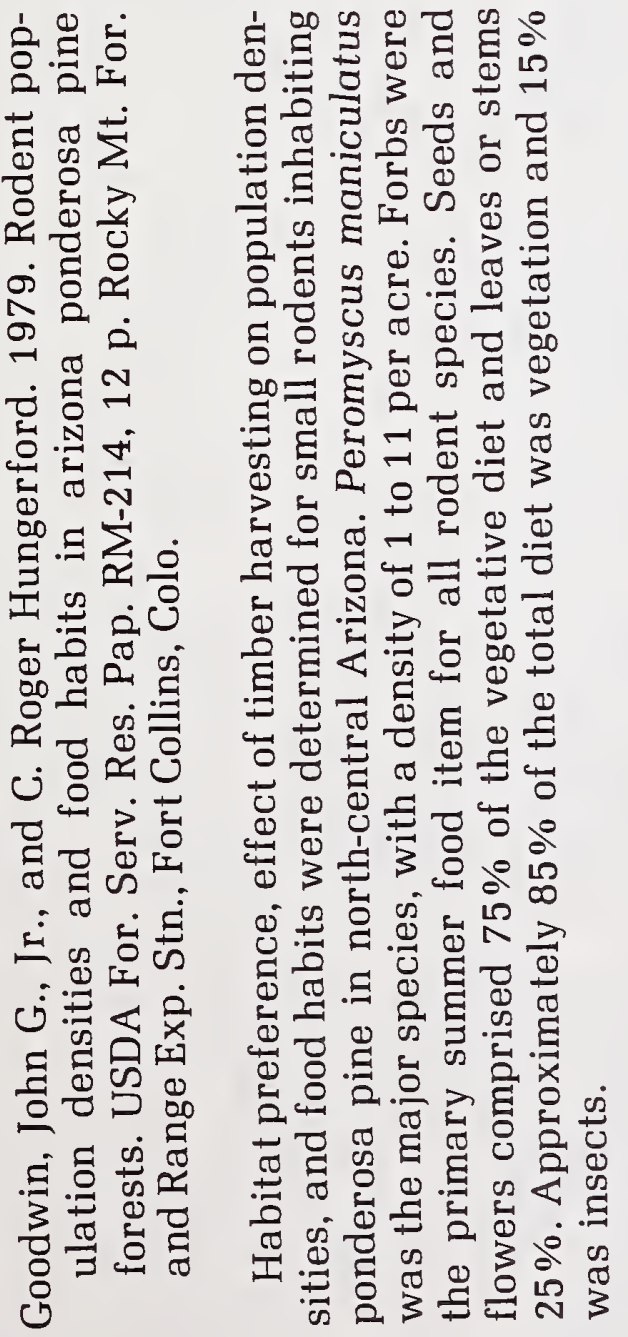

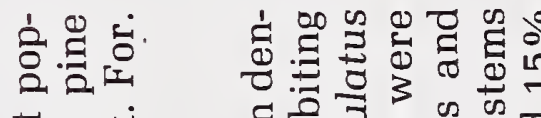

चี

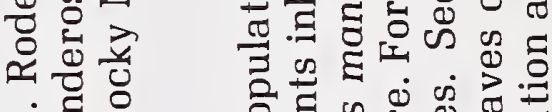

के

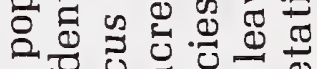

के $\dot{2} \quad \approx 000$

$\rightarrow \pi N$ o

용

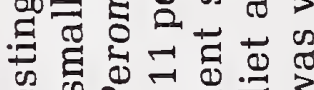

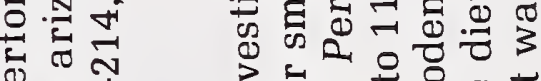

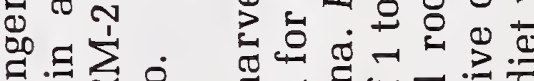

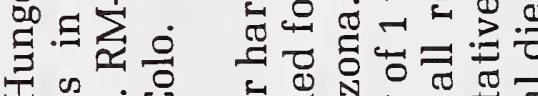

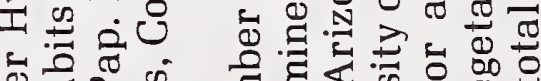

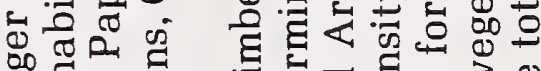

-

x

ن 80

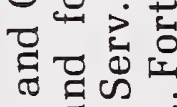

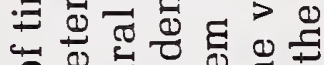

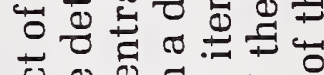

-

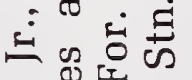

نे

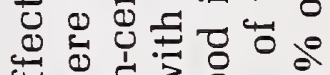

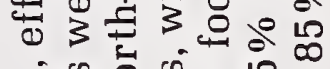

母.

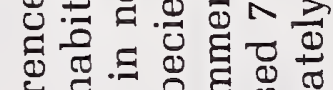

틈요

क्ट

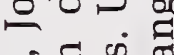

.

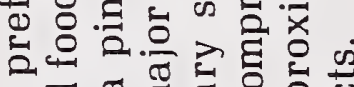

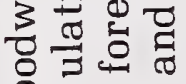

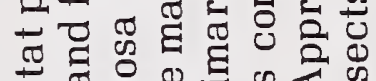

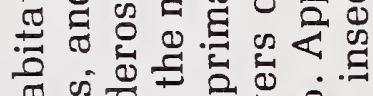
¿ु

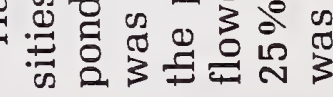

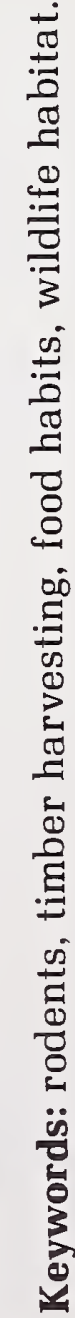




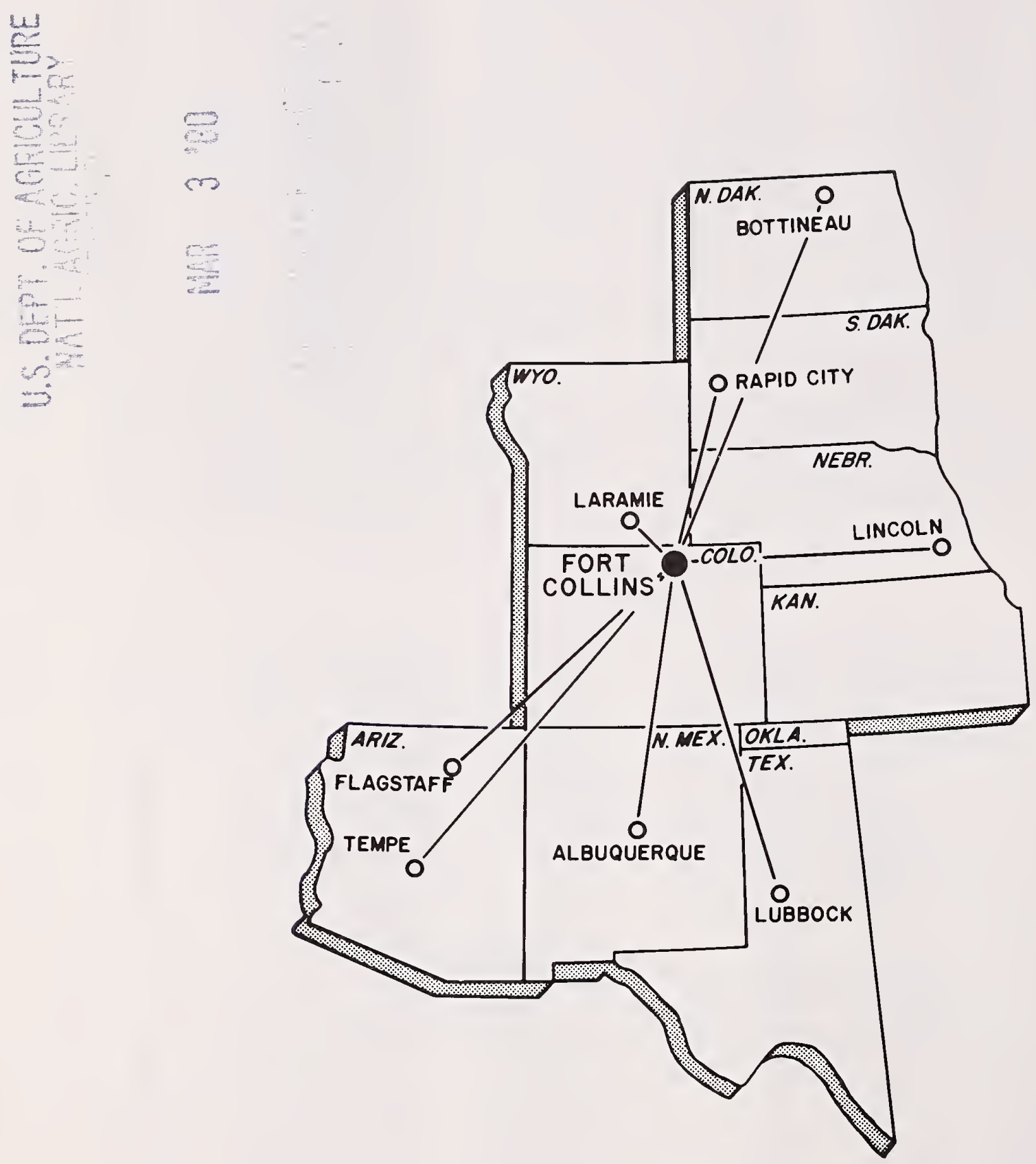

